\title{
SISTEM PENJAMINAN MUTU DAN PENGAWASAN PENDIDIKAN TINGGI
}

\author{
Alwan Suban \\ Universitas Islam Negeri Alauddin Makassar \\ Korespondensi: Jl. Sultan Alauddin No.63, Romangpolong, Kec. Somba Opu, Kabupaten Gowa, Sulawesi \\ Selatan 92113 \\ e-mail: alwan.suban@uin-alauddin.ac.id_
}

soem

\begin{abstract}
This study aims to determine the internal quality assurance system for education standards, research, community service and educational supervision in higher education institutions. The results of the study indicate that all components of the education quality standard must be endeavored to achieve the desired quality, both internal and external stakeholders. Research standards and community service need to be intensified in carrying out an internal quality assurance system by referring to the principles of being educational, accountable, objective, and transparent. Educational supervision in tertiary institutions must always be present to complement the administrative and management processes in achieving educational goals and become an umbrella for inputs, outputs and systems in tertiary institutions to keep activities carried out from deviating from a predetermined plan..
\end{abstract}

Keywords: System of Quality Assurance, Supervision of Higher Education

\section{PENDAHULUAN}

Pendidikan pada dasarnya berfungsi untuk meningkatkan kecerdasan intelektual masyarakat agar dapat menghidupi dirinya sendiri, mengembangkan keterampilan sehingga dapat hidup bersama dengan baik, serta membangun karakter sehingga ikut serta memuliakan dan membangun peradaban maju (Essel1, H. B., Boakye-Yiadom, M. dan Kyeremeh, F. A., 2018). Indonesia menjalankan fungsi pendidikan melalui Sistem Pendidikan Nasional yang mengacu pada Undang-Undang No. 20 tahun 2003 tentang Sistem Pendidikan Nasional.

Persoalan mutu pada pendidikan tinggi menjadi penting untuk dijadikan satu kajian khusus dalam upaya perbaikan pendidikan yang akan berdampak para pembangunan Indonesia di berbagai bidang, karena di pendidikan tinggi inilah para peletak pembuat kebijakan, ilmuan, seniman, dan para perekayasa teknologi seharusnya lahir dengan tidak melulu mementingkan kepintaran, tetapi lebih dari itu pembangunan karakter generasi penerus bangsa ke depan. Banyak faktor yang menjadikan mutu pendidikan tinggi rendah, salah satu diantaranya adalah tidak terlaksananya penjaminan mutu pendidikan tinggi. Penjaminan mutu sendiri seharusnya menjadi satu sistem tersendiri yang menjamin keberlangsungan pendidikan tinggi bermutu (Sri Uchtiawati1 dan Irwani Zawawi, 2014).

Penetapan penjaminan mutu (quality assurance) bagi seluruh Perguruan Tinggi melalui Sistem Penjaminan Mutu Pendidikan Tinggi (SPM Dikti) telah lama diumumkan pemerintah. Berdasarkan Undangundang No. 12 Tahun 2012 tentang Pendidikan Tinggi, SPM Dikti ini meliputi Sistem Penjaminan Mutu Internal (SPMI) dan Sistem Penjaminan Mutu Eksternal (SPME) 
atau yang lebih dikenal dengan Akreditasi. SPM Dikti merupakan sistem penjaminan mutu internal dan external. Adanya kebijakan tentang sistem penjaminan mutu Pendidikan tinggi dari Direktorat Jenderal Pendidikan Tinggi, Kementerian Pendidikan sebagai sebuah program induk pengembangan pendidikan tinggi sebagai upaya peningkatan mutu pendidikan tinggi. Sistem penjaminan mutu pendidikan tinggi ini, merupakan integrasi dari sistem penjaminan mutu internal dan eksternal setelah dikeluarkannya Peraturan Pemerintah (PP) No. 19 Tahun 2005 tentang Standar Pendidikan Nasional yang antara lain menyebutkan bahwa setiap satuan pendidikan pada jalur formal dan nonformal wajib melakukan penjaminan mutu pendidikan.

Berdasarkan Undang-undang No. 12 Tahun 2012 tentang Pendidikan Tinggi, SPM Dikti ini meliputi Sistem Penjaminan Mutu Internal (SPMI) dan Sistem Penjaminan Mutu Eksternal (SPME) atau yang lebih dikenal dengan Akreditasi. Jadi SPM Dikti itu sistem penjaminan mutu internal dan external. Kebanyakan perguruan tinggi lebih mementingkan akreditasi atau SPME dari pada mementingkan SPMI, memang akreditasi selalu menjadi tujuan peningkatan mutu prodi atau Perguruan Tinggi. Begitu akreditasi keluar institusi tidak lagi melakukan evaluasi mutu secara internal. Dalam Undang-undang tersebut, proses SPMI harus dilakukan perguruan tinggi minimal setiap setahun sekali. Jika prodi atau Perguruan Tinggi hanya meningkatkan mutu semata guna mencapai nilai akreditasi baik, ada kecenderungan mutu internal tidak akan meningkat. hal terpenting guna mencapai akreditasi yang baik ialah dengan menerapkan pola Continuous Quality Improvement (CQI). Dengan meningkatkan mutu internal terlebih dahulu, dapat dipastikan proses akreditasi juga akan baik (Worthen, H. \& Berry, J., 2002).

Perguruan Tinggi sebagai lembaga pendidikan tinggi formal, sampai saat ini masih dianggap sebagai sumber ilmu pengetahuan, etika dan nilai kebijakan. Anggapan tersebut telah melekat pada setiap perguruan tinggi, sehingga mutu lulusannya diharapkan memiliki kriteria "smart' dan "good, Namun di sisi lain, kondisi perguruan tinggi di Indonesia masih banyak yang belum melaksanakan kegiatan pembelajaran sesuai dengan standar mutu, hingga pada akhirnya kredibilitas perguruan tinggi masih belum memuaskan para stakeholders. Bila penyelenggara pendidikan tinggi di Indonesia tidak segera melakukan upaya-upaya nyata meningkatkan kualitas input, proses, output maupun outcome-nya, maka eksistensi perguruan tinggi tersebut akan semakin surut (Ahmad Sulaiman, Udik Budi Wibowo, 2016).

Fenomena yang terjadi sekarang ini masyarakat Indonesia banyak mencari pendidikan tinggi yang berkualitas ke luar negeri, misalnya ke negara tetangga Malaysia. Meyikapi hal tersebut pemerintah Indonesia pada tahun 2003 melalui Direktorat Akademik mulai menggagas kegiatan Penjaminan Mutu (Quality Assurance) di perguruan tinggi. Merujuk pada UndangUndang Nomor 20 tahun 2003 tentang Sistem Pendidikan Nasional, Higher Education Long Term Strategy (HELTS) 2003-1010, dan Peraturan Pemerintah No 19 tahun 2005 
tentang Standar Nasional Pendidikan pelaksanaan penjaminan mutu di perguruan tinggi merupakan kegiatan yang wajib dilakukan. Sistem penjaminan mutu perguruan tinggi (PT) dilakukan atas dasar Penjaminan Mutu Internal (PMI), Penjaminan Mutu Eksternal (PME), dan Evaluasi Program Studi Berbasis Evaluasi Diri (EPSBED) yang dikaitkan dengan perijinan penyelenggaraan program studi.

Namun persoalan yang dihadapi penjaminan mutu bukan semata masalah akreditasi program studi, tetapi juga masalah akreditasi institusi akuntabilitas publik, penjaminan mutu internal (evaluasi diri) yang tidak berjalan sesuai prosedur semestinya, tidak adanya standar mutu internal perguruan tinggi, tidak adanya organisasi penjamin mutu internal dan sebagainya. Persoalan ini bukan semata masalah kinerja organisasi, tetapi juga menyangkut masalah kebijakan makro, dan implementasinya di lapangan. Hal ini tentunya tidak hanya memperlemah penjaminan mutu, tetapi juga memperlemah perbaikan mutu perguruan tinggi secara keseluruhan. bermutu (Sri Uchtiawati1 dan Irwani Zawawi, 2014).

Berdasarkan hasil evaluasi Direktorat Jenderal Pendidikan Tinggi Kementerian Pendidikan Nasional (2008) tentang implementasi penjaminan mutu internal di perguruan tinggi dinyatakan bahwa:

1. Sebagian besar perguruan tinggi belum memahami secara utuh fungsi dan peran penjaminan mutu bagi pengembangan dan keberlanjutannya.

2. Sebagian besar perguruan tinggi belum memahami tentang Sistem Pen jaminan Mutu Perguruan Tinggi (SPM-PT) yang digagas oleh Ditj en Dikti.
3. Sebagian besar perguruan tinggi masih memokuskan pada penjaminan mutu internal bidang akademik (hanya focus pada aspek pembelajaran).

4. Sebagian besar perguruan tinggi masih dalam taraf pengadaan dokumen, baik dokumen kebijakan, manual penerapan kebijakan standar mutu.

5. Sebagian kecil perguruan tinggi telah mengimplementasikan penjaminan mutu internal secara penuh (memiliki kelengkapan dokumen kebijakan, manual penerapan kebijakan standar mutu, dan mengimplementasi-kannya).

Merujuk hasil evaluasi dari Direktorat Jenderal Pendidikan Tinggi tahun 2008 di atas maka perguruan tinggi perlu secara kritis melihat kembali peran dan kinerjanya selama ini. Kualitas menjadi kepedulian dan perlu mendapat perhatian serius baik lembaga, pemerintah maupun stakeholders yang terkait dengan pendidikan. Peningkatan mutu di setiap lembaga pendidikan bukan sekedar verbalisme, namun harus diwujudkan melalui suatu proses yang disengaja, direncanakan, diorganisir dan dikendalikan semua pihak melalui team work spirit.

Selanjutnya masalah pengawasan pendidikan, pada dasarnya pengawasan pendidikan merupakan sesuatu yang esensial dalam kehidupan organisasi untuk menjaga agar kegiatan yang dijalankan tidak menyimpang dan rencana yang telah ditetapkan. (Caesar, C., 2013). Dengan pengawasan akan diketahui keunggulan dan kelemahan dalam pelaksanaan manajemen, sejak dan awal, selama dalam proses, dan akhir proses manajemen. Istilah pengawasan dalam proses organisasi bersifat umum sehingga terdapat beberapa pengertian yang 
sangat bervariasi seperti mengadakan pemeriksaan secara terinci, mengatur kelancaran, membandingkan dengan standar, mencoba mengarahkan atau menugaskan, serta pembatasannya atau pengekangannya (Essel1, H. B., BoakyeYiadom, M. dan Kyeremeh, F. A. 2018). Namun pala dasarnya pengawasan merupakan fungsi manajemen dimana setiap manajer dapat memastikan bahwa apa yang dikerjakan sesuai dengan yang dikehendaki. Pengawasan terdiri dari kegiatan-kegiatan yang merupakan upaya agar peristiwa dan kegiatan dalam organisasi serasi dengan rencana.

Berdasarkan uraian tersebut di atas, pembahasan dalam makalah ini akan difokuskan pada sistem penjaminan mutu dan pengawasan pendidikan tinggi yang terdiri dari: (1) sistem penjaminan mutu internal untuk penjaminan mutu standar pendidikan, (2) sistem penjaminan mutu internal untuk penjaminan mutu standar penelitian, (3) sistem penjaminan mutu internal untuk penjaminan mutu standar pengabdian masyarakat, dan (4) pengawasan pendidikan dalam lembaga perguruan tinggi.

\section{METODE PENELITIAN}

Penelitian ini menggunakan pendekatan penelitian [ustaka (library research) yaitu dengan melakukan studi pada berbagai buku referensi serta hasil penelitian untuk mendapatkan landasan teori mengenai masalah yang akan diteliti. Peneliti melakukan kajian dan analisis terhadap dokumen-dokumen mutu yang berlaku pada perguruan tinggi. Langkah penelitian yang dilakukan yaitu: (1) penelitin mencatat semua temuan mengenai "masalah penelitian" pada setiap pembahasan penelitian yang didapatkan dalam literaturliteratur dan sumber-sumber, dan atau penemuan terbaru mengenai "masalah penelitian"; (2) Peneliti memadukan segala temuan, baik teori atau temuan baru; (3) Penelitian melakukan analisis berbagai bacaan, berkaitan dengan kekurangan tiap sumber, kelebihan atau hubungan masingmasing tentang topik yang dibahas; dan (4) Penelitia melakukanKritik dan memberikan gagasan terhadap temuan yang diperoleh,

\section{HASIL PENELITIAN DAN PEMBAHASAN}

\section{Sistem Penjaminan Mutu Internal}

Pengertian Sistem Penjaminan Mutu Pendidikan Tinggi adalah kegiatan sistemik untuk meningkatkan mutu pendidikan tinggi secara berencana dan berkelanjutan. Sementara itu, mutu pendidikan tinggi adalah tingkat kesesuaian antara penyelenggaraan pendidikan tinggi dengan Standar Dikti yang terdiri atas SN Dikti dan Standar Dikti yang Ditetapkan oleh Perguruan Tinggi. Sistem penjaminan mutu tersebut adalah proses perencanaan, pemenuhan, pengendalian, dan pengembangan standar pendidikan tinggi secara konsisten dan berkelanjutan, sehingga pemangku kepentingan (stakeholders) internal dan eksternal perguruan tinggi, yaitu mahasiswa, dosen, karyawan, masyarakat, dunia usaha, asosiasi profesi, pemerintah memperoleh kepuasan atas kinerja dan keluaran perguruan tinggi (Ditjen Dikti, 2008).

Mutu perguruan tinggi adalah kesesuaian antara penyelenggaraan perguruan tinggi dengan standar nasional 
pendidikan (SNP), maupun standar yang ditetapkan oleh perguruan tinggi sendiri berdasarkan visi dan kebutuhan dari para pihak yang berkepentingan (Ditjen Dikti, 2008). Dengan demikian, terdapat standar mutu perguruan tinggi yang ditetapkan oleh Pemerintah (government); disepakati bersama di dalam perguruan tinggi (vision); dikehendaki oleh berbagai pihak yang berkepentingan (stakeholders).

Perguruan tinggi dinyatakan bermutu, apabila perguruan tinggi mampu memenuhi SNP ditinjau dari aspek imperatif, mampu menetapkan dan mewujudkan visinya melalui pelaksanaan misinya dari aspek deduktif, dan mampu memenuhi kebutuhan stakeholders dari aspek induktif. Pemerintah menetapkan beberapa kegiatan sebagai bentuk pengawasan 1 Dosen terhadap Sistem Penjaminan Mutu Perguruan Tinggi (SPMPT), yaitu Pangkalan Data Perguruan Tinggi (PDPT) Nasional, Sistem Penjaminan Mutu Internal (SPMI) dan Sistem Penjaminan Mutu Eksternal (SPME).

Sistem Penjaminan Mutu Internal (SPMI) merupakan kegiatan sistemik penjaminan mutu penyelenggaraan pendidikan tinggi di perguruan tinggi oleh perguruan tinggi (internally driven), untuk mengawasi penyelenggaraan pendidikan tinggi oleh perguruan tinggi sendiri secara berkelanjutan (continuous improvement), sebagaimana diamanatkan dalam Pasal 50 ayat (6) UU Sisdiknas juncto Pasal 91 PP No. 19 tahun 2005 tentang SNP.

Sedangkan Sistem Penjaminan Mutu Eksternal (SPME) adalah kegiatan sistemik penilaian kelayakan program dan/atau perguruan tinggi oleh BAN-PT atau lembaga mandiri di luar perguruan tinggi yang diakui pemerintah, untuk mengawasi penyelenggaraan pendidikan tinggi untuk dan atas nama masyarakat, sebagai bentuk akuntabilitas publik sebagaimana diamanatkan oleh Pasal 60 ayat (2) UU Sisdiknas dan Pasal 86 ayat (3) PP No. 19 Tahun 2005 tentang SNP yang disebut akreditasi.

Mutu pendidikan adalah nilai, manfaat, kesesuaian dengan suatu spesifikasi tertentu atas input, proses, dan output pendidikan yang dirasakan oleh pemakai jasa pendidikan. Menurut permendiknas Nomor 63 Tahun 2009 pasal 1 disebutkan bahwa "Mutu pendidikan adalah tingkat kecerdasan kehidupan bangsa yang dapat diraih dari penerapan sistem pendidikan nasional".

Selanjutnya tujuan Sistem

Penjaminan Mutu Perguruan Tinggi adalah menjamin pemenuhan Standar sicepiPendidikan Tinggi secara sistemik dan berkelanjutan, sehingga tumbuh dan berkembang budaya mutu dan menciptakan sinergi antara PDPT, PMI, dan PME untuk memenuhi atau melampaui Standar Nasional Perguruan Tinggi oleh perguruan tinggi, untuk mendorong upaya penjaminan mutu pendidikan tinggi yang berkelanjutan di Indonesia.

Sedangkan Tujuan penjaminan mutu adalah memelihara dan meningkatkan mutu pendidikan tinggi secara berkelanjutan, yang dijalankan secara internal untuk mewujudkan visi dan misi PT, serta untuk memenuhi kebutuhan stakeholders melalui penyelenggaraan tridharma perguruan tinggi. Hal tersebut dapat dilaksanakan 
secara internal oleh PT yang bersangkutan, dikontrol dan diaudit melalui kegiatan akreditasi yang dijalankan oleh Badan Akreditasi Nasional (BAN) Perguruan Tinggi atau lembaga lain secara eksternal. Sehingga obyektifitas penilaian terhadap pemeliharaan dan peningkatan mutu akademik secara berkelanjutan di suatu perguruan tinggi dapat diwujudkan.

Selanjutnya Fungsi Sistem

Penjaminan Mutu Pendidikan Tinggi adalah mengendalikan penyelenggaraan pendidikan tinggi oleh perguruan tinggi untuk mewujudkan pendidikan tinggi yang bermutu. Struktur dan Mekanisme Sistem Penjaminan Mutu Pendidikan Tinggi yang ditetapkan dalam Permenristek dikti No. 62 Tahun 2016 tentang SPM Dikti sebagai berikut:

1. Struktur SPM Dikti SPM Dikti tersusun dalam suatu struktur yang terdiri atas:

a. SPMI, yaitu kegiatan sistemik penjaminan mutu pendidikan tinggi oleh setiap perguruan tinggi secara otonom untuk mengendalikan dan meningkatkan penyelenggaraan pendidikan tinggi secara berencana dan berkelanjutan.

b. SPME, yaitu kegiatan penilaian melalui akreditasi untuk menentukan kelayakan dan tingkat pencapaian mutu program studi dan perguruan tinggi.

c. PD Dikti, yaitu kumpulan data penyelenggaraan pendidikan tinggi seluruh perguruan tinggi yang terintegrasi secara nasional.

Hal tersebut sejalan dengan tujuan SPM pendidikan tinggi yaitu, menjamin pemenuhan Standar Dikti secara sistemik dan berkelanjutan sehingga tumbuh dan berkembang Budaya Mutu di setiap perguruan tinggi di Indonesia. Dengan demikian, implementasi SPM Dikti dengan struktur seperti di atas harus mampu menjamin pemenuhan Standar Dikti secara sistemik dan berkelanjutan. Adapun Standar Dikti terdiri atas:

1. SN Dikti yang ditetapkan dalam Peraturan Menristekdikti No. 44 Tahun 2015 Tentang Standar Nasional Pendidikan Tinggi adalah satuan standar yang memuat kriteria minimal sistem pendidikan di Indonesia, terdiri atas: Pedoman Sistem Penjaminan Mutu Pendidikan Tinggi

a) Standar Nasional Pendidikan;

b) Standar Nasional Penelitian1;

c) Standar Nasional Pengabdian Kepada Masyarakat.

2. Standar Dikti yang Ditetapkan oleh Perguruan Tinggi yang harus melampaui SN Dikti meliputi:

a) Standar Pendidikan Tinggi bidang akademik;

b) Standar Pendidikan Tinggi bidang nonakademik.

Selanjutnya sistem penjaminan mutu pendidikan tinggi adalah sistem yang dibentuk untuk menjamin mutu perguruan tinggi, dengan cara melaksanakan tiga macam kegiatan, yaitu:

1. Pangkalan Data Pendidikan Tinggi (PDPT) Kegiatan pengumpulan, pengolahan, penyimpanan, pembaharuan, dan pengelolaan data serta informasi oleh perguruan tinggi dan Ditjen untuk mengevaluasi pemenuhan SNPT (dahulu disebut EPSBED) serta pemetaan mutu oleh 
BPSDMPK dan PMP; Quality Assurance Office.

2. Penjaminan Mutu Internal (PMI) Kegiatan evaluasi diri perguruan tinggi oleh perguruan tinggi sendiri (internally driven), untuk memenuhi atau melampaui SNPT secara berkelanjutan/continuous improvement (dahulu disebut Penjaminan Mutu Perguruan Tinggi);

Penjaminan Mutu Eksternal (PME), kegiatan penilaian kelayakan perguruan tinggi oleh BAN-PT atau lembaga mandiri di luar perguruan tinggi yang diakui Pemerintah, berdasarkan SNPT atau standar yang melampaui SNPT yang ditetapkan oleh perguruan tinggi sendiri (disebut Akreditasi).

\section{SPMI untuk Penjaminan Standar Mutu Pendidikan}

Standar Nasional Pendidikan yang mengacu pada Permenristekdikti No. 44 Tahun 2015 mencakup komponenkomponen standar: 1) kompetensi lulusan; 2) isi pembelajaran; 3) proses pembelajaran; 4) penilaian pembelajaran; 5) dosen dan tenaga kependidikan; 6) sarana dan prasarana pembelajaran; dan 7) pembiayaan pembelajaran. Seluruh komponen standar dalam lingkup standar mutu pendidikan harus diusahakan untuk mencapai mutu yang diinginakan baik stakeholder internal maupun eksternal.

Peningkatan mutu penyelenggaraan pendidikan di perguruan tinggi dititik beratkan pada penciptaan proses pembelajaran yang aktif, efektif, efisien, dan kondusifagar dapat memberikan bekal kemampuan akademis dan profesional kepada mahasiswa, sehingga lulusan yang dihasilkan siap bersaing di pasar global (Ahmad Sulaiman, Udik Budi Wibowo, 2016).

Upaya pencapaian mutu yang diharapkan tentu tidak terlepas dari dukungan kepemimpinan serta proses manajerial yang baik untuk meningkatkan etos kerja civitas akademika demi terciptanya lingkungan akademik yang kondusif. Kemampuan manajerial ialah faktor penting dan strategis dalam kerangka peningkatan mutu dan kemajuan perguruan tinggi yang dipimpinnya. Pemimpin perguruan tinggi yang bertanggung jawab harus menyadari bahwa perkembangan dan peningkatan mutu pengelolaan organisasi menjadi sangat penting (Amir, F. 2015). Oleh Karena itu, untuk dapat mengungkap mengenai kinerja, hasil dan dampak perguruan tinggi secara periodik dan teratur, harus dilakukan evaluasi sebagai bagian dari pola managemen perguruan tinggi (Tampubolon, D.P, 2001).

SPMI sebagai alat untuk menjamin pencapaian mutu standar pendidikan harus menetapkan lingkup yang memiliki indikator mutu agar memudahkan proses pengevaluasian pada saat proses audit berlangsung. Akan tetapi indikatorindikator tersebut hanya merupakan pedoman untuk mengukur efisiensi mutu pembelajaran.Evaluasi yang baik harus dapat menjelaskan hal-hal yang diperkirakan dapat dianggap sebagai atribut mutu perguruan tinggi, yaitu: 1) relevansi tujuan dan sasaran; 2) efisiensi; 3) produktivitas; 4) efektivitas, dan 5) akuntabilitas (Almadani, K., Reid, N. dan Rodrigues, S. 2011). 
Standar kompetensi lulusan perguruan tinggi meliputi kompetensi untuk seluruh mata kuliah serta pengelompokan mata kuliah, termasuk di dalamnya adalah mencakup unsur sikap, pengetahuan dan keterampilan, sehingga dalam penerapannya standar kompetensi lulusan tidak terlepas dari standar isi pembelajaran. Pada ruang lingkup ini, LPM melalui SPMI akan memastikan bahwa setiap program studi telah merumuskan standar kompetensi lulusan berdasarkan spesifikasi program studi melalui implementasi kurikulum yang mengacu pada KKNI serta program studi harus menciptakan atmosfir akademik yang sesuai dengan standar mutu kompetensi lulusan yang ditetapkan. Kurikulum haruslah sesuai dengan visi dan misi program studi serta mendukung visi dan misi perguruan tinggi. SPMI akan mendorong implementasi kurikulum dengan menjabarkannya melalui dokumen-dokumen kurikulum yang selalu dimutakhirkan secara periodik serta adanya kebijakan untuk meningkatkan suasanam akademik yang baik melalui penyelenggaraan seminar, simposium, lokakarya sesuai dengan rumpun ilmu program studi.

Ruang lingkup standar proses pembelajaran meliputi perencanaan pembelajaraan hingga pelaporan hasil evaluasi pembelajaran. Dalam hal ini SPMI berfungsi untuk memastikan bahwa proses pembelajaran bersifat interaktif, holistik, saintifik, tematik, efektif, kolaboratif, integratif, dan kontekstual sesuai dengan KKNI dengan beban belajar mahasiswa sesuai dengan peraturan yang telah ditetapkan. Standar penilaian pembelajaran memiliki ruang lingkup penilaian dari pihak dosen dan mahasiswa, dimana hasil evaluasi oleh dosen terhadap mahasiswa akan tercantum dalam kartu hasil studi mahasiswa dan penilaian mahasiswa terhadap dosen akan dievaluasi oleh LPM yang diteruskan kepada pimpinan perguruan tinggi.

SPMI melalui proses audit internal mutu harus memastikan bahwa program studi memiliki standar penilaian, teknik dan instrument penilaian, mekanisme dan prosedur penilaian hingga pelaporan penilaian sehingga melalui hasil audit internal mutu, standar proses ini akan terus mengalami peningkatan. Pada lingkup pendidikan tinggi, tenaga kependidikan yang memiliki kualifikasi sebagai pendidik disebut dengan dosen, sedangkan tenaga kependidikan lain disebut sebagai tenaga penunjang penyelenggaraan pendidikan. Dosen yang telah memenuhi kualifikasi akademik dan professional akan diajukan sebagai dosen tetap, sedangkan jika dibutuhkan, program studi akan mendayagunakan dosen tidak tetap untuk memenuhi kebutuhan penjaminan mutu program akademik. Dalam hal ini, SPMI akan memastikan bahwa program studi memiliki sistem seleksi, sistem pengembangan, system retensi serta pemberhentian dosen dan tenaga kependidikan yang mengacu pada Permendikbud No. 49 Tahun 2014 mengenai standar dosen dan tenaga kependidikan.

Dalam rangka pemenuhan capaian pembelajaran lulusan, maka standar sarana dan prasarana memiliki peran penting untuk mendukung kebutuhan proses 
belajar mengajar. SPMI harus menjamin bahwa standar sarana dan prasarana yang disiapkan oleh perguruan tinggi telah sesuai dengan PERMENDIKBUD No. 49 Tahun 2014.Melalui SPMI, standar sarana dan prasarana pendidikan akan terus dievaluasi agar selalu memadai, bermutu baik, mudah diakses dan digunakan setiap saat serta selalu mengalami perkembangan untuk memenuhi kebutuhan civitas akademika.

Standar pengelolaan pembelajaran meliputi proses perencanaan, pelaksanaan, pengendalian, pemantauan dan evaluasi serta pelaporan kegiatan belajar mengajar dalam program studi yang harus dievaluasi secara periodik melalui SPMI untuk meningkatkan mutu proses pembelajaran dan menciptakan suasana akademik yang baik. Untuk mendukung kegiatan pembelajaran perguruan tinggi, maka komponen standar pembiayaan pembelajaran harus memiliki perencanaan yang baik meliputi biaya investasi pendidikan tinggi serta biaya operasional pendidikan tinggi (Adegbesan, S. O. 2011). SPMI harus menjamin bahwa tujuan utama rencana anggaran pendapatan dan belanjaialah untuk mengembangkan perguruan tinggi melalui implementasi tri dharma perguruan tinggi.

\section{SPMI untuk Penjaminan Standar Mutu Penelitian}

Pendidikan tinggi menyelenggarakan kegiatan penelitian dan pengabdian kepada masyarakat dengan menjunjung tinggi nilainilai persatuan bangsa sehingga mampu menghasilkan lulusan yang kompeten (Kadek Hengki Primayana, 2015: 13). Penelitian dalam dunia pendidikan merupakan kegiatan untuk memperoleh data untuk membuktikan suatu kebenaran atau ketidakbenaran suatu asumsi atau hipotesis menurut kaidah dan metode ilmiah yang dilakukan secara sistematis bagi kemajuan ilmu pengetahuan dan teknologi. Pada lingkup perguruan tinggi, kegiatan penelitian bertujuan untuk mengembangkan teori dan ilmu pengetahuan sehingga output dari produk penelitian dapat berupa tugas akhir, skripsi, tesis atau disertasi, publikasi ilmiah, buku ajar, produk atau paten.

LPM melalui SPMI harus menjamin bahwa penelitian di perguruan tinggi memiliki standar hasil penelitian yang bermutu demi perkembangan ilmu pengetahuan dan teknologi.Penelitian harus memiliki standar isi penelitian dengan kedalaman dan keluasan materi penelitian yang memuat prinsip kemanfaatan, kemutakhiran, serta dapat menjawab kebutuhan masyarakat. Lembaga penelitian dan pengabdian kepada masyarakat merupakan lembaga yang mewadahi bidang penelitian dan pengabdian kepada masyarakat. SPMI akan memonitoring dan mengevaluasi kesesuaian perencanaan terhadap pelaksanaan penelitian, apakah penelitian telah dilaksanakan sesuai dengan road map LP2M, serta memiliki kesesuaian antara pelaksanaan, isi, waktu, serta anggaran dana penelitian dengan proposal.

Program studi harus memiliki standar peneliti dengan melihat kualifikasi akademik serta penguasaan peneliti terhadap metodologi penelitian serta menyediakan standar sarana dan prasarana penelitian yang harus memenuhi standar kenyamanan, kesehatan, serta keamanan 
peneliti yang harus dipastikan pengembangannya melalui SPMI. Kegiatan penelitian program studi harus sesuai dengan rencana induk penelitian perguruan tinggi yang didukung dengan kelengkapan dokumen untuk mendukung pelaksanaan penelitian serta pengendalian mutu penelitian.Hal ini berguna sebagai indicator standar pengelolaan penelitian yang dievaluasi melalui SPMI.

Perguruan tinggi wajib menyediakan dana penelitian internal bagi setiap dosen tetap untuk mengembangkan kemampuan dosen di bidang penelitian, selain itu Perguruan tinggi wajib memfasilitasi pengembangan penelitian melalui kerjasama dengan instansi di luar perguruan tinggi. L2M akan menetapkan indikator pencapaian kinerja yang akan diaudit dan dievaluasi secara periodik melalui SPMI.

\section{SPMI untuk Penjaminan Standar Mutu Pengabdian kepada Masyarakat}

Menurut UU No 12 Tahun 2012 Pasal 47 tentang Pendidikan tinggi, pengabdian kepada masyarakat merupakan kegiatan sivitas akademika dalam mengamalkan ilmu pengetahuan dan teknologi untuk memajukan kesejahteraan umum dan mencerdaskan kehidupan bangsa. Di lingkup Perguruan tinggi, standar mutu pengabdian kepada masyarakat meliputi standar hasil, standar isi, standar proses, standar penialaian, standar pelaksana, standar sarana dan prasarana, standar pengelolaan, serta standar pendanaan dan pembiayaan pengabdian kepada masyarakat (Hedwig, R. \& Polla, G., 2006).

Pengabdian kepada masayarakat mencakup pengembangan ilmu pengetahuan dan teknologi yang mencakup prinsip kemanfaatan, kemutakhiran serta menjawab kebutuhan masyarakat dengan hasil penelitian berupa publikasi, buku ajar atau modul pelatihan serta inovasi produk atau ilmu yang tepat guna bagi masyarakat. Setiap kegiatan pengabdian kepada masyarakat harus terdiri atas perencanaan, pelaksanaan, dan pelaporan kegiatan pengabdian kepada masyarakat yang harus dimonitoring dan dievaluasi kesesuaiannya melalui kegiatan SPMI.Kegiatan pengabdian kepada masyarakat harus dinila mengacu pada prinsip edukatif, akuntabel, obyektif, serta transparan dimana standar penilaian pengabdian kepada masyarakat telah diatur dalam PERMENDIKBUD No 49 Tahun 2014 Pasal 58.

LPM melalui SPMI harus memastikan bahwa melalui kegiatan pengabdian kepada masyarakat, akan terjadi perubahan sikap dan perubahan keterampilan dengan adanya pengetahuan baru yang disampaikan kepada masyarakat, serta kegiatan ini dapat mengatasi masalah sosial dengan memanfaatkan ilmu pengetahuan dan teknologi. SPMI akan menjamin bahwa pihak yang terlibat dalam kegiatan pengabdian kepada masyarakat memiliki kemampuan dan keahlian sesuai dengan bidang kegiatan, serta kegiatan pengabdian kepada masyarakat memiliki tingkat kedalaman sasaran kegiatan dengan melibatkan dosen dan mahasiswa. SPMI juga akan menjamin bahwa Perguruan Tinggi akan memfasilitasi sarana dan prasarana yang memadai terkait kegiatan pengabdian kepada masyarakat dengan mempertimbangkan standar mutu 
keselamatan kerja, kenyamanan, serta keamanan. Idealnya, seluruh kegiatan perencanaan, pelaksanaan, pengendalian, monitoring dan evaluasi, serta pelaporan kegiatan pengabdian kepada masyarakat harus selaras dengan rencana strategis pengabdian kepada masyarakat yang dirancang oleh Perguruan Tinggi, sehingga proses ini juga tidak terlepas dari mekanisme pendanaan dan pembiayaan internal untuk kegiatan pengabdian kepada masyarakat yang diatur oleh Perguruan Tinggi. Melalui SPMI, akan dipastikan bahwa telah terjadi kesesuaian pengelolaan pendanaan untuk proses seleksi proposal, monitoring dan evaluasi, pelaporan, diseminasi hasil pengabdian kepada masyarakat, serta peningkatan kualifikasi pengabdi.

Dalam pengembangan penjaminan mutu diperlukan sikap profesional ialah mereka yang berkomitmen secara penuh tanggung jawab pada tugasnya menuju keunggulan mutu (Markum, M.E. (2007). Menurut Markum, M.E. (2007) secara umum pelaksanaan penjaminan mutu dilakukan dalam tiga tahapan: a) kesepakatan tentang kebutuhan yang akan dipenuhi agar tercapai kepuasaan; b) menentukan kegiatan - kegiatan yang akan dinilai kualitasnya, dan c) melakukan prosedur yang memastikan bahwa kualitas selalu terpelihara. Menurut Mishra, S. (2007) indikator sebuah perguruan tinggi mampu memberi efek manfaat dimensional kepada lingkungan, ketika mampu menjawab masalah kontekstual yang ada.

Untuk menuntaskan urgensi SPMI, maka tentu harus diperkuat dengan asas yang ada di perguruan tinggi, seperti menanamkan bahwa perguruan itu sebagai:

1. Penghasil tenaga kerja yang bermutu. Dalam pengertian ini pendidikan tinggi merupakan suatu proses dan mahasiswa dianggap sebagai output yang mempunyai nilai dalam pasaran kerja, dan keberhasilannya diukur dengan tingkat penghasilan yang mereka peroleh saat berkarier.

2. Lembaga pelatihan bagi karier peneliti. Mutu perguruan tinggi ditentukan oleh prestasi penelitian dosen dan mahasiswa. Jika mutu dan tanggung jawab dosen meningkat maka proses pendidikan semakin berkualitas. Jika proses pendidikan berkualitas tentu hasil pendidikan pun berkualitas. Ukuran masukan dan keluaran dihitung dengan jumlah staf yang mendapat penghargaan/ memenangkan hibah dari hasil penelitiannya, baik di tingkat nasional maupun internasional.

3. Organisasi pengelola pendidikan yang efisien. Dalam pengertian ini perguruan tinggi dianggap baik jika hubungannya dengan sumber daya dan dana yang tersedia, jumlah mahasiswa yang melalui proses pendidikannya semakin besar.

4. Upaya memperluas pengkayaan kehidupan. Pertumbuhan jumlah mahasiswa dan variasi jenis progam yang ditawarkan. Rasio Dosen - Mahasiswa yang sesuai dengan regulasi, adanya pembiayaan yang tidak hanya berasal dari biaya perkuliahan, juga dipandang sebagai ukuran keberhasilan perguruan tinggi.

\section{Pengawasan Pendidikan}

Dalam literatur manajemen, pengawasan diartikan sebagai proses 
pengamatan terhadap pelaksanaan seluruh kegiatan organisasi untuk menjamin agar semua pekerjaan yang sedang dilaksanakan berjalan sesuai dengan rencana yang telah ditetapkan sebelumnya. Pengawasan dimaksudkan untuk menunjukan kelemahan dan kesalahan kemudian membetulkannya dan mencegah perulangannya. Pengawasan dalam konsep ini berkaitan dengan orang, kegiatan dan benda (Husaini Usman, 2008.).

Di dalam lembaga pendidikan seperti sekolah atau perguruan tinggi, pengawasan harus selalu hadir untuk senantiasa melengkapi proses adininistrasi dan manajemen untuk selanjutnya mencapai tujuan pendidikannya. Atau dengan kata lain, pengawasan harus menjadi payung bagi input, output dan proses tadi, atau sistem di satuan pendidikan. Terutama dalam tahap prosesnya. Tujuannya untuk menjaga agar kegiatan yang dijalankan tidak menyimpang dan rencana yang telah ditetapkan. Atau, secara umum fungsi pengawasan menjadi faktor utama dalam adininistrasi pendidikan (Husaini Usman, 2008).

Istilah pengawasan dalam organisasi bersifat umum, sehingga terdapat beberapa pengertian yang bervariasi seperti mengadakan pemeriksanaan secara terinci, mengatur kelancaran, membandingkan dengan standar, mecoba mengarahkan atau menugaskan, serta untuk pembatasannya atau pengekangan (Pandong, A., 2003). Namun pada dasarnya pengawasan merupakan fungsi manajemen dimana setiap manajer untuk memastikan bahwa apa yang dikerjakan sesuai denagn yang dikehendaki.

Pengawasan dalam pendidikan berarti mengukur tingkat efektivitas kerja personil pendidikan dan tingkat efisiensi penggunaan sumber-sumber daya pendidikan dalam upaya mencapai tujuan pendidikan. Berdasarkan pengertian ini sasaran pengawasan pendidikan tidak hanya dalam substansi manajemen, akan tetapi juga menyangkut kegiatan professional yang harus diselenggarakan sebagai beban kerja setiap personil pendidikan/unit kerja yang ada (Pandong, A., 2003).

Dalam beberapa pengertian di atas, pada dasarnya pengawasan mempunyai dua unsur pokok, yaitu: 1) pengawasan menekankan kepada proses dan 2) pengawasan diarahkan kepada koreksi dan membandingkan dengan tujuan.

Selanjutnya fungsi pengawasan dalam lembaga pendidikan, tentunya akan membentuk sebuah kultur oiganisasi pendidikan yang sehat atau progresif. Dalam artian, pengawasan menjadi sebuah kultur atau operating system dalam organisasi. Terutama dalam adininistrasi dan manajemen satuan pendidikan. Secara birokratif, fungsi pengawasan adalah untuk mengungkap penyimpangan penyimpangan yang terjadi dalam pelaksanaanya sehingga hal itu menjadi bahan untuk melakukan perbaikan agar lebih professional (Sahertian, P.A., 2000).

Berdasarkan konsep tersebut, pelaksanaan pengawasan di perguruan tinggi harus mencakup pengendalian yang bersifat administrative dan akademik atau proses pengajaran. Tetapi dalam prakteknya pelaksanaan pendidikan yang selama ini diterapkan cenderung hanya menyangkut aspek material saja seperti pemeriksaan keuangan, fasilitas, tata usaha kantor, sedangkan pengamatan dan pengendalian terhadap proses belajar mengajar sering kali 
luput dari perhatian. Bahkan pengawasan terhadap keseluruhan aspek dari fungsi manajemen pun tetap belum terlaksana (Sahertian, P.A., 2000).

Pengawas di lembaga pendidikan selama ini lebih menonjolkan segi fisik, seperti pengelolaan dana, alat, bangunan, dan pegawai yang kurang mendapat perhatian, padahal merupakan sasaran yang amat penting, adalah pengawasan terhadap penyelenggaraan proses belajar mengajar yang berlangsung (Pandong, A., 2003).

\section{Pengawasan Pendidikan dalam Lembaga Perguruan Tinggi}

Pada dasarnya pengawasan pendidikan dalam lembaga perguruan tinggi merupakan sesuatu yang sangat esensial bertujuan untuk menjaga agar kegiatankegiatan yang dijalankan tidak menyimpang dari rencana yang telah ditetapkan. Dengan pengawasan akan diketahui keunggulan dan kelemahan dalam pelaksanaan manajemen, sejak dari awal, selama dalam proses, dan akhir pelaksanaan manajemen. Keberhasilan proses pengawasan ditentukan oleh penilaian yang secara rinci dapat dapat memberikan umpan balik berupa gambaran yang jelas tentang tingkat keberhasilan dalam mencapai tujuan dan sasaran yang dikehendaki (Tomlinson, $\mathrm{H}$. 2004).

Dalam kaitan ini jelaslah bahwa pengawasan pendidikan dalam lembaga perguruan tinggi mencakup pengendalian, penilaian, pelaksanaan dan pengambilan tindakan penertiban yang sifatnya represif dan preventif terhadap kegiatan manajemen dalam organisasi. Oleh karena pengawasan dapat berfungsi sebagai suatu alat pencegah terjadinya penyimpangan. Apabila dalam tindakan pengawasan dikemukakan hambatan atau penyimpangan hendaknya diambil tindakan positif berupa perbaikan atau perubahan dalam pelaksanaannya (Tomlinson, $\mathrm{H}$. 2004).

Dalam manajemen pendidikan, tindakan pengawasan dan penilaian merupakan dua fungsi yang sangat erat kaitannya. Dengan demikian fungsi pengawasan dan penilaian pendidikan tidak hanya memeriksa tindakan yang disesuaikan dengan peraturan yang berlaku, tetapi sebaiknya menjadi motor penggerak pembaharuan pendidikan, dan dapat membina lembaga pendidikan yang baik (Depdikbud, 1981). Implikasi dari pendekatan ini ialah, bahwa derajat produktivitas sistem manajemen pendidikan ditentukan oleh mekanisme kerja sistem pengawasan dan penilaian pendidikan yang dikembangkan oleh pengelola, disamping partisipasi bawahan/staf yang lebih bermotivasi dalam operasionalisasi program tersebut.

Secara umum telah dikemukakan bahwa hasil pengawasan dapat memberikan manfaat bagi perbaikan dan peningkatan efektivitas proses manajemen organisasi. Lebih lanjut Wiles, J. \& Bondi (2003) mengemukakan bahwa fungsi pengawasan antara lain :

1. Memperoleh data yang setelah diolah dapat dijadikan dasar bagi usaha perbaikan kegiatan dimasa yang akan datang.

2. Memperoleh cara bekerja yang paling efisien dan efektif atau yang paling tepat dan paling berhasil sebagai cara yang 
terbaik untuk mencapai tujuan.

3. Memperoleh data tentang hambatanhambatan dan kesukaran-kesukaran yang dihadapi, agar dapat dikurangi atau dihindari.

4. Memperoleh data yang dapat dipergunakan untuk meningkatkan usaha pengembangan organisasi dan personil dalam berbagai bidang.

5. Mengetahui seberapa jauh tujuan telah tercapai.

Pengawasan terdiri dari kegiatankegiatan yang merupakan upaya agar peristiwa dan kegiatan dalam organisasi serasi dengan rencana. Meskipun setiap organisasi mempunyai karakteristik yang berbeda (tergantung pada misi, jenis, bentuk dan sebagainya), tetapi dalam kegiatan pengawasan semua organisasi melaksanakan tahapan-tahapan pokok yang sama. Tahapan-tahapan tersebut yaitu : penentuan standar, pengukuran, perbandingan hasil pengukuran dengan standar, dan upaya "correction action" Sahertian, P.A, (2000).

\section{PENUTUP}

Berdasarkan kajian analisis dan temuan pada penelitian ini, maka dapat ditarik beberapa kesimpulan yaitu:

1. Sistem Penjaminan Mutu Internal untuk penjamin standar mutu pendidikan yang mengacu pada Permenristekdikti No. 44 Tahun 2015 mencakup komponenkomponen standar yaitu, 1) kompetensi lulusan; 2) isi pembelajaran; 3) proses pembelajaran; 4) penilaian pembelajaran; 5) dosen dan tenaga kependidikan; 6) sarana dan prasarana pembelajaran; dan 7) pembiayaan pembelajaran. Seluruh komponen standar dalam lingkup standar mutu pendidikan harus diusahakan untuk mencapai mutu yang diinginakan baik stakeholder internal maupun eksternal.

2. Sistem Penjaminan Mutu Internal untuk penjamin standar mutu penelitian merupakan kegiatan untuk memperoleh data dalam membuktikan suatu kebenaran atau ketidakbenaran suatu asumsi atau hipotesis menurut kaidah dan metode ilmiah yang dilakukan secara sistematis bagi kemajuan ilmu pengetahuan dan teknologi. Pada lingkup perguruan tinggi, kegiatan penelitian bertujuan untuk mengembangkan teori dan ilmu pengetahuan sehingga output dari produk penelitian dapat berupa tugas akhir, skripsi, tesis atau disertasi, publikasi ilmiah, buku ajar, produk atau paten.

3. Sistem Penjaminan Mutu Internal untuk penjamin standar mutu pengabdian kepada masyarakat yang mencakup pengembangan ilmu pengetahuan dan teknologi dalam bidang prinsip kemanfaatan, kemutakhiran serta menjawab kebutuhan masyarakat dengan hasil penelitian berupa publikasi, buku ajar atau modul pelatihan serta inovasi produk atau ilmu yang tepat guna bagi masyarakat. Kegiatan pengabdian kepada masyarakat harus dinilai mengacu pada prinsip edukatif, akuntabel, obyektif, serta transparan dimana standar penilaian pengabdian kepada masyarakat telah diatur dalam PERMENDIKBUD No 49 Tahun 2014 Pasal 58.

4. Pengawasan pendidikan dalam lembaga perguruan tinggi harus selalu hadir untuk senantiasa melengkapi proses adininistrasi dan manajemen dalam 
mencapai tujuan pendidikan dan juga harus menjadi payung bagi input, output dan system dalam lembaga perguruan tinggi. Tujuannya adalah untuk menjaga agar kegiatan yang dijalankan tidak menyimpang dan rencana yang telah ditetapkan.

\section{KEPUSTAKAAN ACUAN}

Adegbesan, S. O. 2011. Establishing Quality Assurance in Nigerian Educationsystem: Implication for Educational Manage. Educational Research and Reviews, 6 (2), 147-151.

Ahmad Sulaiman, Udik Budi Wibowo, 2016. Implementasi Sistem Penjaminan Mutu Internal sebagai Upaya Meningkatkan Mutu Pendidikan di Universitas Gadjah Mada. Jurnal Akuntabilitas Manajemen Pendidikan, 4 (1), 17-32.

Almadani, K., Reid, N. dan Rodrigues, S. 2011. Quality Assurance: A Pressing Problem For Education in the 21st Century. Problems of Education in the 21st Century, Vol. 32.

Amir, F. 2015. Developing Structure for Management of Quality in Schools: Steps towards Quality Assurance Systems. American Journal of Educational Research, 3 (8), 977-981.

Caesar, C. 2013. Framework for Delivery of Quality Education: Examination of quality concepts to inform a framework for improving education quality in St Lucia a member of the Organization of Eastern Caribbean states (OECS). American Academic \& Scholarly Research Journal, 5 (1). Charles E. Merrill Publishing Company A Bell \& Howell Company.
Darman, Darwin, dan Yusnadi. 2017. Implication of Internal Quality Assurance System of Schools Implementation Against the Accreditation rating of State Senior High Schools of Natuna, Riau Island Province. Journal of Research \& Method in Education, 7 (5), 36-39.

Departemen Pendidikan Nasional. Mishra, S. 2007. Quality Assurance in Higher Education: An Introduction. Bangalore, India: National Assessment and Acreditation Council.

Ditjen Dikti Depdiknas. 2003. Pedoman Penjaminan Mutu (Quality Assurance) Pendidikan Tinggi. Jakarta: Ditjen Dikti Depdiknas.

Ditjen Dikti Depdiknas. 2004. Strategi Jangka Panjang Pendidikan Tinggi (HELTS) 2003-2010 Menuju Sinergi Kebijakan Nasional. Jakarta: Ditjen Dikti Depdiknas.

Ditjen Dikti Kemendiknas. 2010. Sistem Penjaminan Mutu Perguruan Tinggi (SPMPT). Jakarta: Ditjen Dikti Kemendiknas.

Essel1, H. B., Boakye-Yiadom, M. dan Kyeremeh, F. A. 2018. Assessing Students' Experiences of Internal Quality Assurance Practices in Selected Private Higher Education Institutions. International Journal of Science and Research (IJSR). 7 (1).

Halimatus Sakdiah. 2011. Penjaminan Mutu Internal Perguruan Tinggi, Jurnal Insania. $16(1)$.

Hedwig, R. \& Polla, G. 2006. Model Sistem Penjaminan Mutu dan Proses Penerapannya di Perguruan Tinggi. Yogyakarta: Graha Ilmu. 
Husaini Usman. 2008. Peningkatan Kompetensi Pengawas Sekolah/Madrasah. Jurnal Tenaga Kependidikan. 4 (3).

Kemendiknas. 2009. Permendiknas Nomor 63 Tabun 2009 tentang Sistem Penjaminan Mutu Pendidikan.

Markum, M.E. 2007. Pendidikan Tinggi dalam Perspektif Sejarah dan Perkembangannya di Indonesioa. Jakarta: Direktorat Jenderal Pendidikan Tinggi.

Pandong, A. 2003. Tugas Pokok dan Fungsi Pengawas. Jakarta: Badan Diklat Depdagri \& Diklat Depdiknas.

Presiden. 2005. Peraturan Pemerintah RI Nomor 19 Tabun 2005 tentang Standar Nasional
Pendidikan.

Sahertian, P.A. 2000. Konsep Dasar \& Teknik Supervisi Pendidikan. Jakarta: Bineka Cipta.

Sri Uchtiawati1, Irwani Zawawi. 2014. Jurnal Kebijakan dan Pengembangan Pendidikan. 2 (1), 52-56.

Wiles, J. \& Bondi, J. 2003. Supervision a Guide to Practice. Second Edition. London:

Worthen, H. \& Berry, J. 2002. Bargaining for "Quality" in Higher Education: A Case Study from the City Colleges of Chicago (Versi Elektronik). Labor Studies Journal, 27, 1-23. 